\title{
PAINTED DEDICATION TO GENIUS AND A RELIEF DEPICTING AQUILA FROM A SANCTUARY IN SOPIANAE
}

\author{
(APPENDIX TO THE STUDY: PAINTED DEPICTION OF GENIUS OF SOPIANAE BY ANITA KIRCHHOF)
}

\author{
BOGLÁRKA FÁBIÁN* - ÁDÁM SZABÓ** \\ * Aquincum Museum and Archaeological Park \\ 135 Szentendrei út, H-1031 Budapest, Hungary \\ fabbogi@gmail.com \\ ** Hungarian National Museum. \\ 14-16 Múzeum krt, H-1088 Budapest, Hungary \\ szabo.adam@hnm.hu
}

\begin{abstract}
In the locality of Sopianae, Pannonia Inferior, at the east corner of the settlement, there was a presumably customs station built at the end of the $2^{\text {nd }}$ century which existed till 258-260 AD. From one of the rooms of the building excavated on Kossuth Square, Pécs, a fresco depicting a Genius, an inscription belonging to it, two pedestals - probably bases for statues - and a statue of an eagle came to light. Based on the assemblage the room may have been the sanctuary (sacellum) of the official building. The rare but formal telonium or teloneum expression may have been used for this customs station which, as such, belonged to the organization of the Publicum portorium Illyrici. The only surviving inscription may have been dedicated to the genius of the employees or the armed guards of the customs station: Genio / cu(stodiarum?) tel(onei?). On the pedestal bases probably emperor statues were situated. On the eastern wall of the west-east oriented room, based on its own pedestal and generally because of its quality, there was the relief of an eagle placed in a niche personalizing Iuppiter and the imperial power. In this case the eagle can be taken as a state-imperial symbol found in its own context and thus belonged to the rare Roman Age relics of the administration. The sanctuary must basically serve the official imperial cult.
\end{abstract}

Keywords: Severan Period, Pannonia Inferior, Sopianae, Publicum portorium Illyrici, Genius, Aquila, simulacrum, insignium imperii, fresco, teloneum, sacellum, statio, inscription, customs station, imperial cult

\section{INTRODUCTION}

In 2008, in the northwest corner of Kossuth Square, Pécs, Zsolt I. Tóth excavated a $2^{\text {nd }}-3^{\text {rd }}$ century building built on stone foundation in adobe turned 15 degrees to the west from the quarters. Considering the contemporary topography of Sopianae, Pannonia Inferior, the building was located at the eastern edge of the settlement, near the road running in and out (see Kirchhof Fig. 5). Archaeologist dates its construction to the Severan Period and its abandonment to the second third of the $3^{\text {rd }}$ century, to the period of the barbarian invasion in 258-260 $\mathrm{AD}^{2}{ }^{2}$ Later the building started to erode and collapse, finally was pulled down at the beginning of the $4^{\text {th }}$ century and its place levelled. The greatest destruction was made by late generations with their medieval, early and later modern disturbances. ${ }^{3}$

In the not fully excavated building several rooms can be located. From one, connected to the neighbouring rooms from the south and west, a thin floor layer of mortar, two pedestals, a fragmented fresco, ${ }^{4}$ and a

${ }^{1}$ Our special thanks is to Zsolt István Tóth for the possibility of the publication, the photos, the technical details and the lecturing and to Anita Kirchhof for the drawings and the cooperation in general. Special thanks to Csaba Pozsárkó as well.

${ }^{2}$ See KovÁcs 2014, 241-257.
${ }^{3}$ See Tóтн 2008, 3-19, especially 9-10. As for the description of the provenance and placing the building into its topographicalhistoric context, see also above in the study of A. Kirchhof.

${ }^{4}$ See Tóth 2008, 10-11; see also the summary of $\mathrm{KIRCH}_{-}$ HOF 2018, 124-127.

${ }^{5}$ То́тн 2008, 9 . 


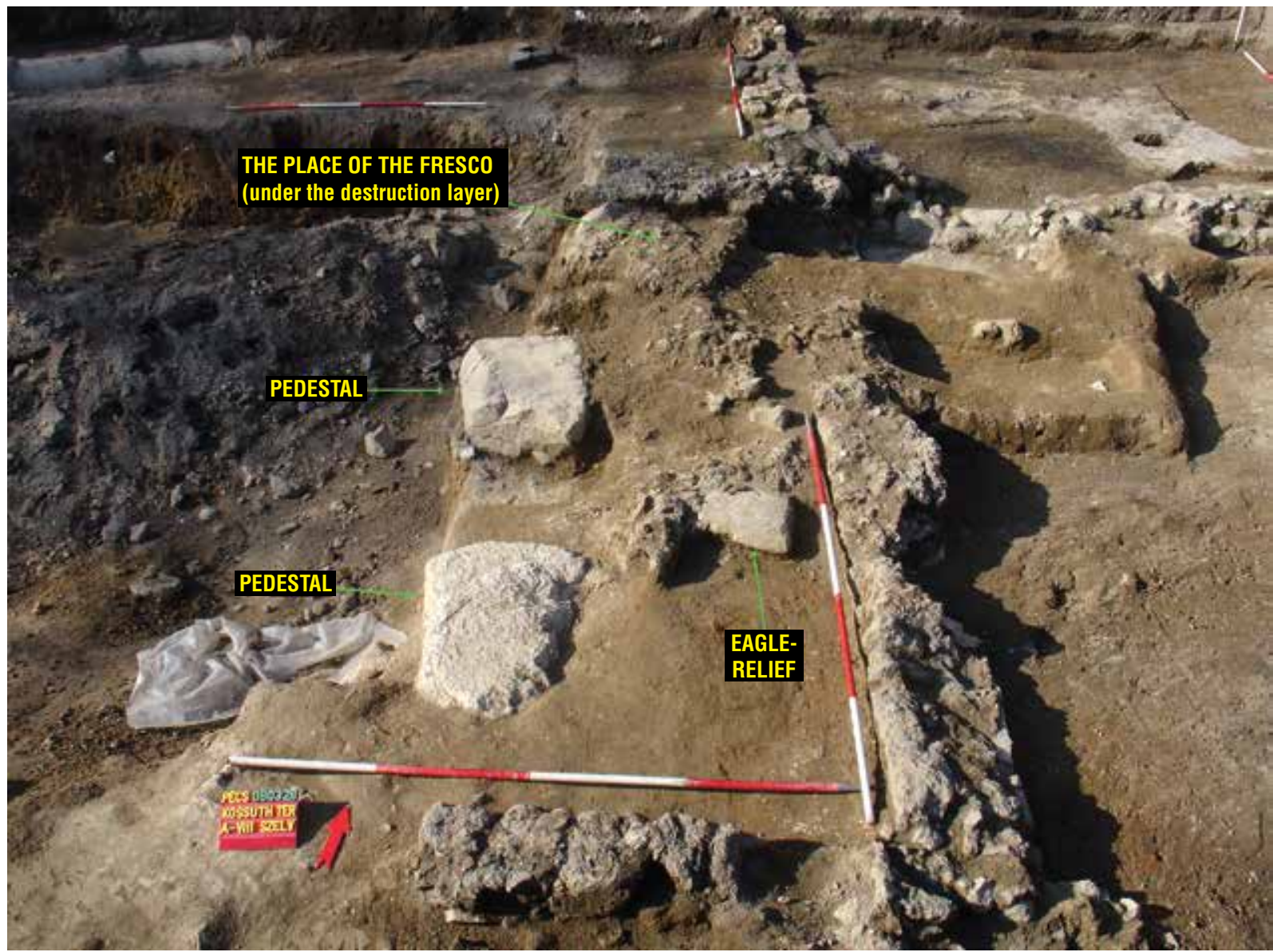

Fig. 1. The excavated sanctuary and its objects (photo: Zs. I. Tóth)

relief $^{5}$ came to light from under the demolition layer (Fig. 1). The fragmented fresco lay in the northeast corner of the room, with its painted side up. The two pedestals interpretable in a structural unity were found next to each other, in front of the eastern wall. Inside the stripe, between the eastern wall and the pedestals, in the axis of the space between the pedestals, near the eastern wall, lay a relief depicting an eagle with its illustrated side upwards. Between the relief and the pedestals a demolition layer of fist-sized rubble and remnants of adobe was found. The surviving finds and the decoration can be interpreted in the same context. The remnants altogether contribute to the definition of the room as a sanctuary such as the interpretation of the individual objects. According to its formal and contextual relationship, the assemblage and the room together with the building may be interpreted within the framework of the imperial administration (see below).

\section{THE PEDESTALS}

The pedestals are roughly processed, averagely 1 metre long and 60 centimetres wide limestone slabs with damaged surfaces. Their surfaces are uneven, their sides are fragmentary, and a larger piece of the southern shorter side and another piece of the longer, western side of the northern one is broken off. They are situated proportionally, as the contextual unity of the room. Both are placed at an even distance from the eastern wall and approximately at the same distances from the northern and southern walls. The vertical surfaces of the pedestals placed roughly in 
the middle of the eastern part of the room are parallel to the walls. The distance between the pedestals is nearly half of the distances between the pedestals and the northern and southern walls. The two pedestals were placed on the floor layer in the room. Based on their arrangement, sizes and the nature of the room, they formed stable foundations of the superstructures - probably statue bases. On these bases statues of emperors may have stood. The two emperors of the time of the building's construction originally had been Septimius Severus (193-211 AD) and Caracalla $(197-216 \mathrm{AD})^{6}$ and just before the abandonment of the building were Valerianus (253-260 AD) and Gallienus (253-268 AD). ${ }^{7}$ During the period between the statues of prevailing co-emperors might have stood in the sanctuary.

\section{THE PAINTED INSCRIPTION}

Most of the fresco that had slid off the northern wall of the room has perished according to the the excavation observations. From its remnants, the beginning of a two line inscription painted in red on a white background (see Kirchhof Fig. 3) and a multicolour head of a Genius can be reconstructed (see Kirchhof Fig. 2). The detailed technical description and evaluation has been carried out by Anita Kirchhof (see above) and based on the assembled fragments she also made a suggestion for its reconstruction (see Kirchhof Fig. 7). She evaluated the Genius depiction from iconographical points of view there, as well.

On the fresco two lines of a fragmentary inscription had remained and to the right, east of it was the Genius depiction. Based on the fragments the fresco probably was extended on the right of the Genius. The brownish, red fragments of lines cannot be considered as further letters. The surviving inscription was painted in red on a white background, in quality actuaria letters used from the Severan Period. The sizes of the by now browned letters: $6.1-6 \mathrm{~cm}$ (line 1), $4.7 \mathrm{~cm}$ (line 2). The first letter of line 1 is fragmented, but based on its sketching and the end of its lower part it is undoubtedly a ' $G$ '. Only the bottom of the next letter has remained but based on its vertical hasta and the two, horizontal hastae springing from it, it is an ' $E$ '. The left hasta of the following letter is missing, however based on the remaining parts it cannot be anything but an ' $N$ '. On the fresco preceding the letter ' $G$ ' there is a big enough space left so if there had been any characters there, they were now probably detecable - thus the letter ' $G$ ' may be taken as the first letter of line 1. Just the same way, on the relatively big space after the last letter, no further character can be seen so the line ends with the letter ' $O$ '. The first letter of the fragment or abbreviation on line 2 is a ' $C$ '. The end of the lower curve of the letter is intact and unmistakable. Based on the fresco fragments left to it, there was nothing in front of it thus the ' $C$ ' is the first letter. Only the top of the second letter has survived. Based on the direction of the fragments and the space left between the preceding and following characters, it cannot be other than a ' $V$ '. We cannot resolve whether they are two, one-letter abbreviations or a single, two-letter abbreviation as the fragment between the letters has been lost. Either possibility is probable. The next character of the line is what divides the two fragments, an interpunctio pointing upwards. The interpunctio is not placed in the very middle of the line, it is a bit lower than that but its approximate shape of an equilateral triangle is definite and it has no extension on any side, only the background surrounds it so it cannot be anything else. The interpunctio is followed by a ' $T$ ' then an ' $E$ ' whose upper, horizontal hasta is below the top of the line and its vertical hasta is drawn to the top of the line. The last letter of the line is a vertical hasta that has no extension either at the top or in the middle but a small start of a horizontal line can be seen at the bottom and based on this, it can only be an ' $L$ '. According to the starting point of the inscription and the arrangement of the fresco, the ' $L$ ' may have been the last letter of the line. We cannot certainly tell if the inscription went on under this. Based on the background belonging to the Genius, in the field surrounded by the garland, the two lines are adjusted to the middle. According to this the inscription belonging of the painted field only consisted of these two lines. The visual appearance of the room was probably not only these now existing part, in all probability it was fully decorated. Several other painted figures and inscriptions similar to the surviving examples, may have been depicted but they have perished.

[Unpublished. Mentioned by A. Kirchhof (see KIRCHHOF 2018, 107 ff., Fig. 3; p. 118), unearthed in 2008, in Kossuth Square, Pécs, the fresco with inscription was taken to the Janus Pannonius Museum, its inventory number: JPM 2.2.2015. It is kept there. Described in 2018.] 
The inscription (see, Fig. 2 and Kirchhof Fig. 3):

GENIO

$C \boldsymbol{V} \bullet T E L$
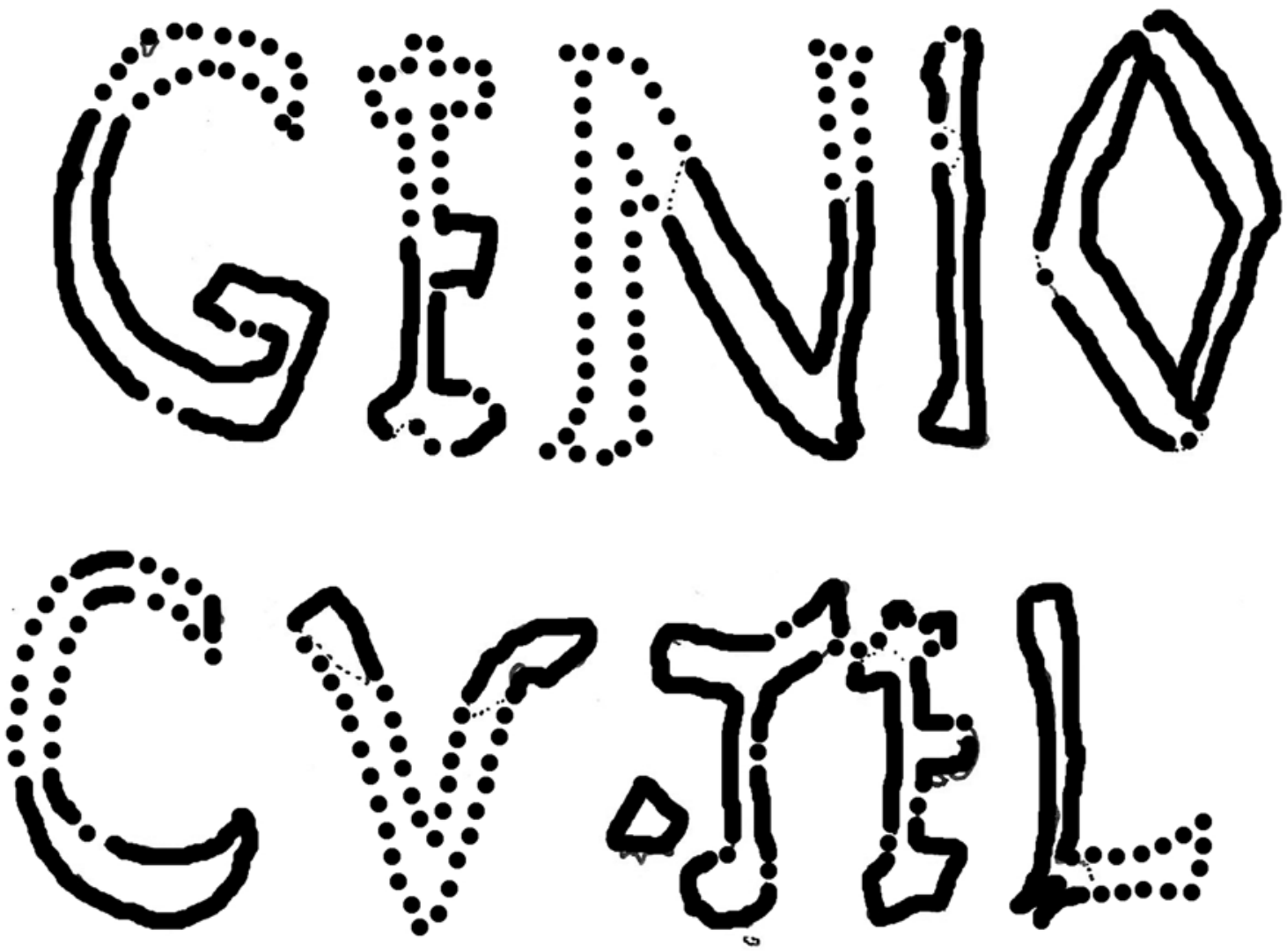

Fig. 2. The drawing of the inscription of the fresco (drawing: A. Kirchhof, Á. Szabó)

Based on the structure of the fresco, the fragmentary inscription was proportionally placed in the middle of the field and comprises a text to be interpreted in its whole.

The first line is well legibly a genius in dative, i. e. a dedication which places the inscription and by this the room into a religious context. 'There is no place without genius' stated Servius in his commentary written to the Aeneis. ${ }^{8}$ Several dedications to genius are know from imperial inscriptions which supports the Servian statement. Practically everything had genii, animate and inanimate, people, communities, troops, societies, places, any natural phenomena, buildings, a geographical-political areas etc. The number of genii is nearly infinite in the Roman world and sources had remained for only a few of them. They were religiously respected as Genii. ${ }^{9}$ Usually it turns out from the dedication whose genius was respected by the author of the inscription as he indicated the adjective or affiliation of the genius. In case neither an adjective nor affiliation is indicated, the place itself interpreted the dedication though this occured rarely. ${ }^{10}$

tus, Vergilii Aeneidos Libros 5.85.1.

${ }^{9}$ The "Clauss-Slaby" (EDCS) online Epigraphic-Database available on the Internet contains nearly 1600 dedications to Genius or mentions of Genius on 20 February 2018: http://db.edcs.eu/epigr/ epi_ergebnis.php: “Genius, Genium, Genii, Genio".

${ }^{10}$ See summarized WISSOWA 1912, 175-181 and KUNCKEL 1974. See also VÁmos 2008, 251-258, for earlier literature. 

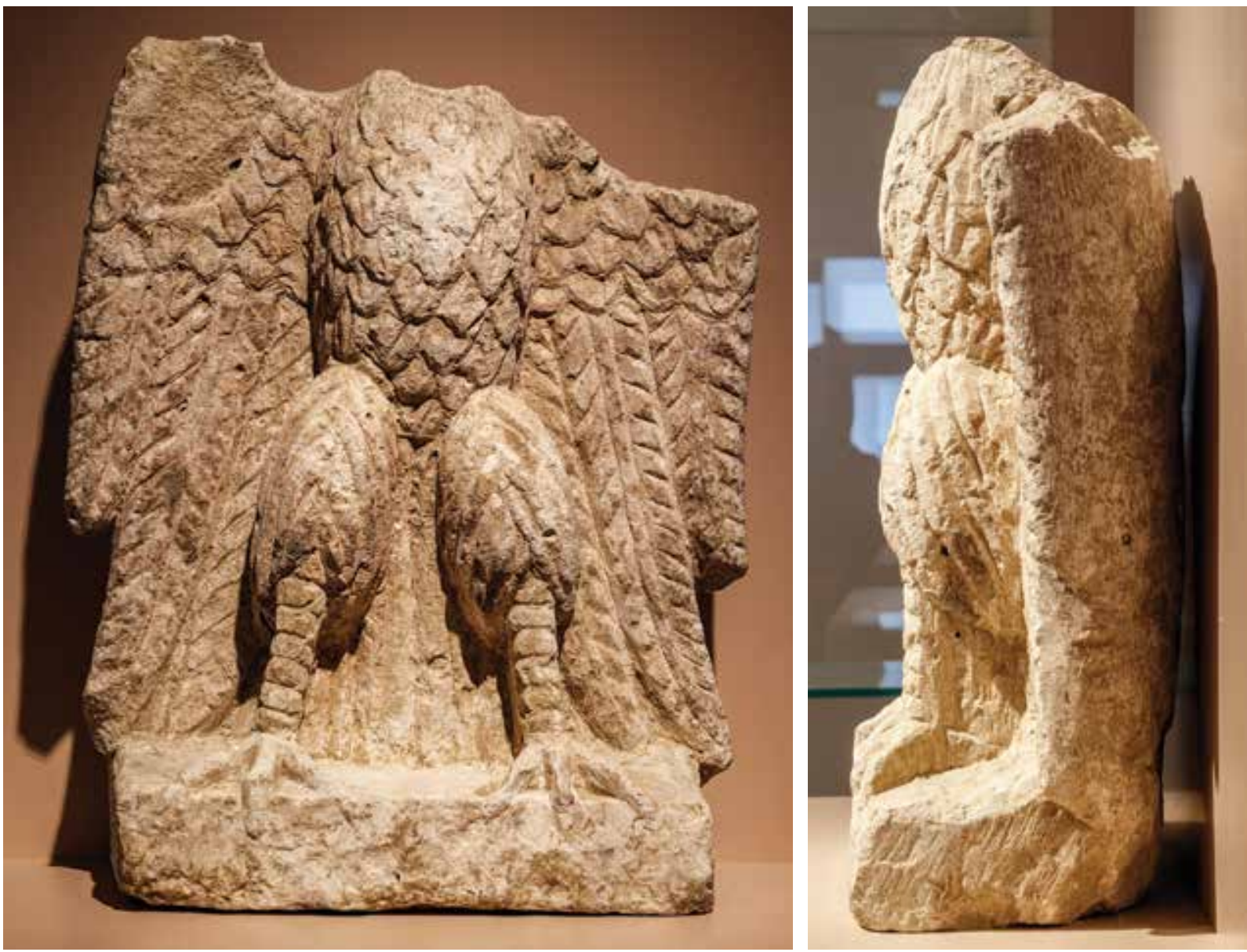

Fig. 3. a: The relief of the eagle from the front (photo: Zs. I. Tóth); 3b: The relief of the eagle from the side (photo: Zs. I. Tóth)

Under the above outlined condition that the inscription was not proceded in any other field, the ' $C V$ ' abbreviation of line 2 must be the adjective or affiliation of the Genius which defines its status. In this case, beginning with ' $C V$ ', the adjective Cucullatus known from Noricum is unlikely for the local nature of Genius Cucullatus on one hand, and the Genius figure depicted on the fresco on the other. Other Genius adjective beginning with ' $C V$ ' is not known so the abbreviation must only refer to the context the inscription and the painted Genius appears. Due to the outlined context of the room, the resolution of the $C V$ abbreviation appears to be likely derived from the word custos also in lack of other lexical solution. This indicated the affiliation of the Genius with the personnel of the building, part of the personnel or perhaps its armed guards. If the ' $C V$ ' did not belong to the Genius but a person e. g. as an office title (for due to the abbreviation type and the continuation of the inscription, it may not be a personal name), it should stand after the next abbreviation. The TEL group of letters separated from the $C V$ abbreviation by an interpunctio could even be the name of the person who erected an altar in a formal inscription. In this case however, the line should start with the TEL group which could indeed be interpreted as a name. Cognomina beginning with Tel- are known but there are much more left for us as to be able to identify the name from their threeletter abbreviation. ${ }^{11}$ Due to the arrangement of the fresco, its continuation in a following line is unlikely as well as the continuation in another inscription field may be excluded. The TEL abbreviation thus may refer to the institution in which the sanctuary-room (sacellum) with the fresco and eagle statue was erected. In this regard it may be the determination of the more detailed affiliation of the Genius. The location itself explained the inscription so the more

${ }^{11}$ See Kajanto 1965, 50, 52, 156, 187, 338: Telesianus, Telesinus, Telesius, Tellianus, Tellus and LÖRINCZ 2002, 111: Telamo, Telassicus, Telcus, Teleius, Telemachus, Telephus, Teles, Telesilla, Te- lesinus, Telesphorianus, Telesphorinus, Telesphoris, Telesphorus, Telest, Telete, Telionnus, Tellonius, Tellus, Telta. 
unusual abbreviations must have been clear for the contemporary reader, especially if there were other inscriptions in other painted fields in the room and in the building. By excluding personal names, there remains a lexical phrase which appears both at auctores sources and in inscriptions, and offers a plausible version of interpretation. The word

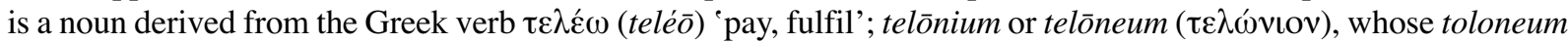
version is also known. The not very frequent word was used to mark customs stations, usually the building itself. ${ }^{12}$ In the texts of the early empire, Suetonius refers to the grouped use of the term, ${ }^{13}$ Tertullian uses the word referring to leaving the customs station (teloneum) ${ }^{14}$ and it appears four times on inscriptions. Three of the inscriptions are known from Africa proconsularis while one from Asia proconsularis. According to a constructional inscription in Mheimes, Africa, the vicarius vilici had the teloneum renovated and dedicated it to Venus Augusta. ${ }^{15}$ The inscription in Annaba (Hippo Regius) was dedicated to the Numen of the emperor and Venus Augusta by a libertine who was a procurator telonei maritimi that is, the leader of the harbour's customs station. ${ }^{16}$ The possible religious implications of the telonea are well outlined by the examples from Africa. The fragmentary, probably constructional inscription from Gafsa (Capsa) was erected by the verna vectigalis, the vilicus and the contrascriptor of the customs station (here: toloneum) between 209 and $211 .{ }^{17}$ The epitaph from Ephesus was erected by a teloniarius to his wife. ${ }^{18}$ Even if from the auctores the official use of the expression may not be expected, the few inscripted examples show the official use of it. Not only it appears in case of a simple employee (teloniarius) or as we can see at Suetonius, of a publican, but also in the titles of high ranking customs officers (procurator telonei). On the other hand, similarly to how Tertullian also used it, it appears as the denomination of an office building (teloneum), which a vicarius vilici renovated. In spite of these from another telonium, the office of the vilicus, the verna vectigalis and the contrascriptor is known. According to this the telonium known from the Tertullian places also reflects the official term. In his case it is not important where and when the referred story took place but what phrase he used for a customs station in his own age, at the last quarter of the $2^{\text {nd }}$ and the first of the $3^{\text {rd }}$ centuries. The term used by him for the customs station was understood by the whole readership who knew Latin so it has to be considered empire wide spread. The term occasionally also appears in the Late Roman-Early Byzantine in legal sources. ${ }^{19}$

Within the imperial customs system ${ }^{20}$ Sopianae belonged to the customs district of Illyricum, to the Publicum portorium Illyrici. ${ }^{21}$ In the terminology of the customs district and the region of Illyricum, usually the terms portorium and vectigal appear in connection with customs, customs offices and the customs stations were generally called stationes. Nevertheless the customs officer ranks vilicus, vicarius vilici, verna vectigalis, contrascriptor existed in the district of the Publicum portorium Illyrici as well as the procurator rank of the leader of the district from $174 \mathrm{AD}^{22}$ The similarly designated offices refer the terms telonium, portorium and vectigal into a similar contextual and organizational framework. The vicarius vilici rank of the renovator of the telonium in Mheimes expresses the telonium belonging to a larger customs district. The same is indicated by the existence of the vilicus, verna vectigalis and contrascriptor in Gafsa (Capsa). In these cases the larger organizational unit was the Quattuor publica Africae..$^{23}$ It can be stated that the branch office buildings established in smaller settlements belonging to larger organizational units were or may have been called telonia which were probably the counterparts of customs

\footnotetext{
${ }^{12}$ See LeClercQ 1926, 423-424.

${ }^{13}$ Suetonius, De vita Caesarum libri VIII: Divus Vespasianus 1.2: "KA $\Lambda \Omega \Sigma \mathrm{TE} \Lambda \Omega \mathrm{NH} \Sigma \mathrm{ANTI}$ " regarding the publican father of the emperor.

${ }^{14}$ Tertullianus, De Idololatria 12.3: ,... cum Matthaeus de teloneo suscitatur..." and Tertullianus, De baptismo 12.45: „... uno verbo domini suscitatus teloneum ..." See New Testament (Novum Testamentum), Matthew 9.9-13 and Luke 5.27-32.

${ }^{15}$ CIL VIII 12314 = ILS 1654 = LBIRNA 882, Africa proconsularis / Mheimes: Veneri Aug(ustae) sac(rum) / Delius Abascanti Aug(usti) vil(ici) vic(arius) teloneum a funldamentis sua impensa r[e] stituit et ampliavit.

${ }^{16}$ Corbier 1981, 90-92 No. 2 = AE 1982, 944, Africa proconsularis / Annaba (Hippo Regius): [Numi]ni Aug(usti) et I [Ven]eri Aug(ustae) sacr(um) / [- - - ] Aug(usti) lib(ertus) proc(urator) telonei(!) maritumi(!) d(e) s(ua) p(ecunia) f(ecit).

${ }^{17}$ AE 1996, $1702=$ AE 2000, 1602: Africa proconsularis / Gafsa (Capsa): - - - - - ] I M(arci) Aureli An]toni[ni - - -] / [ [- - -]]

Aug[- - -] I [- - - Iuliae] Domnae Aug[ustae - - ] I [- - -]m toloneum(!) [- - - ] I [- - -]pione verna vec[tigal - - ] I [- - -]a vil(ico) Capsae e[- -] I [- - - c]ontrascriptor [e - - -] I [- - - - - .

${ }^{18}$ CIL III 13677 = IK 162296 = BREsson 2016, $320:$ Asia proconsularis / Ephesus: Dis Man(ibus) I Olympiadi Q(uintus) I teloniarius / coniug(i) karis/sim [ae] v(ivus) f(ecit).

${ }^{19}$ Codex Theodosianus 11.28.3; 13.1.1. (KRÜGER 1923); Legum novellarum Divi Valentiniani XIII.1 (MOMMSEN-MEYER 1905); Corpus Iuris Civilis: Iustiniani novellae constitutiones XXX. VI.1., CVI.pr., CXXIII.VI. (SCHOELL 2014).

${ }^{20}$ See De LaEt 1949 and Vittinghof 1953.

${ }^{21}$ See Dobó 1940; De LAET 1949, 175-346; GudEA 1996,

75-99.

${ }^{22}$ See also GudEA 1996, 131-134; PISo 2013, 293-333.

${ }^{23}$ See for further literature DE LAET 1949, 247-271; VitTinghoF 1953, 346-399; Dupuis 2000, 277-294. 
stations or local branch offices called stationes elsewhere. The example of Annaba (Hippo Regius) where the teloneum was lead by a procurator who would lead larger organizational units elsewhere does not contradict with the determination of the telonea as smaller units within larger units as the known procuratores did not always have the same duty. ${ }^{24}$ In the harbour of Hippo Regius, the commercial traffic may have justified that the teloneum within the customs district of Africa needed a larger office apparatus which therefore was ordered under the administration of a procurator.

In most cases, however, the telonea must have been smaller office buildings inside towns. This is also probably the reason why there are hardly any inscriptions left of the word especially if they did not have constructional inscriptions or the denominations of the buildings were inscribed on easily perishable frescos. Therefore by the above proposal for interpretation, the building in Sopianae was a customs office, in fact a statio which, according to the fresco, was called as telonium or teloneum by the employees working there, referring to the building itself.

The early imperial military, official and civilian communities respected their common Genii in general, therefore these genii may appear with the most diverse adjectives and affiliations in the inscribed resources. ${ }^{25}$

The presumable Genius cu(stodiarum?) may well fit among them.

According to the above, the below interpretation can be proposed for the inscription on the fragmentary fresco in Pécs:

Genio

cu(stodiarum?) tel(onei?).

The interpretation is the most probable taking the condition of the inscription as well as the context into account. In case there was an interpunctio between the letters ' $C$ ' and ' $V$ ', other interpretations could also be propounded but there is no sign of interpunctio between the two letters. The proposal for interpretation can be made by the administrative function of the building and by the sacred function of the room inside. The building stood near the edge of the settlement and near a road so it befits the general topographical criteria of the contemporary customs stations. ${ }^{26}$

\section{THE EAGLE RELIEF}

It is a high-relief ('haut-relief' or 'alto rilievo') of limestone, standing on a pedestal with extended wings (37.5)x30x13 cm. (Fig. 3a-3b) Carved from a single piece, half-life-size. There are some burnt spots on its surface. Its head, neck and the upper parts of its wings are broken off, lost. A piece of the inner side of its right wing has broken off. There is no sign of the posture of its head - it probably turned to sideways, possibly to the left. From the front at the bottom, with flat surfaces on three sides, there is a rectangular cut, prism shaped pedestal to the upper corner of which holds the bird itself with its curved, strong claws. The claws are carved to the details. Above them, the legs of the eagle are also detailed, its skin is marked with horizontal carvings. On its bulging, muscular thigh, the feathers are individually detailed. The feathers of its breast are imbricate. So are the feathers on the inside of its wings, while the longer feathers are detailed with vertical and cross carvings and the richness of the feathering was depicted by the artist with connecting, slantwise carvings. Its wings are anatomically well detailed, approximating to a naturalistic depiction. The back of the statue is carved to a smooth, bulging surface. The proportions of the piece, despite its stylisation, approximate to the natural are a product of a provincial artist of excellent quality. Its schematic depiction with the extended wings and its characteristics has an impression of an insigne. According to its shape, its own pedestal and its main view, it may have been placed in a niche.

Unearthed in 2008 inside the room, it was lying with its front down, near the middle of the eastern wall, at the west-east axis of the empty space between the pedestals, with its head pointing to the west. Its proximity to the eastern wall and the posture of its bottom suggest that originally it was fixed on the eastern wall, behind the statues

\footnotetext{
${ }^{24}$ See for all the variations of the procurator rank summarizing Pflaum 1960/61 and Pflaum 1982.
}

\footnotetext{
${ }^{25}$ See e. g. the catalogue of inscriptions by Doвó 1940 and see also DOMASZEWSKI $1895 \mathrm{~b}$ and the catalogues of inscriptions of CB 1990 etc.

${ }^{26}$ See De LaEt 1949, 45-55; VitTinghof 1953, 347-349.

Acta Archaeologica Academiae Scientiarum Hungaricae 69, 2018
} 
on the pedestals (see above) in the middle and fell from there into the demolition layer. During the demolition of the building and the levelling of the area it was either not noticed or due to its back side it was mistaken for a piece of stone thus it could remain in place. It was taken to the Janus Pannonius Museum, its inventory number: JPM 2.1.2015. It is kept there.

[Described in 2018. Unpublished. Its photo presented by Tóth 2008, 14. Mentioned by A. Kirchhof (see KIRCHHOF 2018, 112-118, Fig. 6).]

In each period of the Roman state, the eagle was a determinative symbol it accompanied Roman history from the foundation of the city. It was mainly considered as one of the figures of the main deity of the state, the Capitoline Iuppiter Optimus Maximus. In this role, it is also particular to received deities interpreted as Iuppiter. From 104 BC, as also the exclusive insignia of the base units of the Roman army, the legions, and as such, was religiously respected. During the Imperial Era, it was the symbol of the imperial authority and the state. Due to its nature therefore in the Roman period, the eagle may appear in religious, military and administrative contexts as well. Its depiction represents several varieties, even in the same context, but in each case, unmistakably. Its contexts of depiction are also varied. It appears on plastic creations of different materials, on the back of coins, on terracotta artefacts, and as independent artefacts or as part of compositions of several figures. When depicted, the theoretical content of the eagle took precedence in every context. Beside the depictions, they also appear in textual sources both by the auctores and on inscriptions, in the form of aquila although mainly in military contexts. Its research background also corresponds with this. Despite its administrational aspects, it is mainly discussed in its military context which is understandable considering the origins of its role and importance. As the insignia of the army constituting the basis of the imperial power, from its military context, the eagle derived to the other aspects of the imperial administration as the symbol of the imperium. ${ }^{27}$ As the direct relationship with the person of the emperor, an early expression and good example is the statue of Claudius in Lavinium (Italia), where at the foot of the emperor depicted as Iuppiter, there is the imago of the eagle with extended wings. ${ }^{28}$ Due to its close relationship with the main deity of the state as well as the emperor, ${ }^{29}$ it could symbolize both its individual depictions may be interpreted as the representation of the highest level of the state and the administration.

Despite of its significance, the number of the surviving depictions seems to be low compared to other, known figural creations. ${ }^{30}$ Within this, there are hardly any known pieces of individually depicted eagles both from Pannonia and the provinces of Illyricum. In greater numbers there are known eagle statues from Aquilea that was in a close cultural, commercial and social relationship with Pannonia. In Aquilea, the Publicum portorium Illyrici also had a branch overseeing several stationes. ${ }^{31}$ Among the provinces in Illyricum, the number of statues in Dacia is outstanding. ${ }^{32}$ Some of the standard size and form, full statues or reliefs, well distinguishable from burial monuments and mythological depictions, may have originally been located in the premises of state, imperial offices. There must have been an abundance of the type in the Roman Empire. The small number of the surviving artefacts is not in accordance with their significance in the Roman world, which makes us surmise that they were consciously hidden or destroyed. The latter may have happened during the Late Roman Empire-Early Christian Era, mainly for its religious implications, for its simulacrum ${ }^{33}$ of Iuppiter. $^{34}$

${ }^{27}$ See DomaszewsKi 1895a, 317-318; SESTON 1969, 692711; STOLL 2001, 14 and 18-46. For the repository of eagle depictions based on literature; see also the summary of the role of the eagle in Rome's history by HiMMELMANN-WILDSCHÜTZ 1994, 65-77; TÖPFER $2011,18-21$ etc. in details, 65-67, see there also the imagery of the surviving depictions of eagles.

${ }^{28}$ Musei Vaticani, Museo Pio-Clementino, Inv. No. 243. Vö. Vatican 1986, 49. See also STEWART 2003, 49-51.

${ }^{29}$ See TÖPFER 2008, 32.

${ }^{30}$ See the published volumes of Corpus Signorum Imperii Romani (1964-) Also see BRAEMER 1999, 90-93 and http://www.corpussignorum.org/csir/history.htm.

${ }^{31}$ See e. g. AE 1934, 234, Italia, Regio X / Aquileia, and CIL V 1864 = AE 1997, 580 and AE 2006, 123, Italia, Regio X / Iulium Carnicum (Zuglio).
${ }^{32}$ See e. g. UbiEratLupa (20 February 2018): Italia, Regio X / Aquileia - 13993, 14516, 17670, 18215, 19094; Dacia / Apulum - 19241, Napoca - 21097, 21098, 21099, Dobrosloveni - 21951, Deva - 17860, Sibiu - 17457, Sarmizegetusa - 12310; Dalmatia / Obrovac - 24293.

${ }^{33}$ See Tacitus, Annales 15.29

${ }^{34}$ See e. g. Codex Theodosianus 16.10: De paganis, sacrificiis et templis, especially 16.10.19.1: Simulacra, si qua etiamnunc in templis fanisque consistunt et quae alicubi ritum vel acceperunt vel accipiunt paganorum, suis sedibus evellantur, cum hoc repetita sciamus saepius sanctione decretum; 16.10.19.2: Aedificia ipsa templorum, quae in civitatibus vel oppidis vel extra oppida sunt, ad usum publicum vindicentur. Arae locis omnibus destruantur omniaque templa in possessionibus nostris ad usus adcommodos transferantur; domini destruere cogantur; 16.10.19.3: Non liceat omnino in honorem 
The eagle statue is a special piece of the equipment of the sanctuary in Kossuth Square, Pécs. In the sanctuary, it may have well been religiously respected its role in the given context was the representation of the state, i. e. the emperor (a certain kind of insignium imperii) which strengthens the protection of the administrative function of the building.

\section{SUMMARY}

As a summary it may be stated, that the building was probably a customs station belonging to the Publicum portorium Illyrici. In this regard it was considered as an administratively official place. One of the rooms of the building was furnished as a sanctuary (sacellum) by the people serving in the building and whose primary function was to carry out the official imperial cult. The sanctuary may have been the south-western room in the corner of the not fully excavated building. The painted decoration can be dated to the Severan Period when the construction of the building also took place. According to the results of the excavations the Severan decoration remained until 258-260 AD when the building was abandoned. Consequently, it was being maintained in its unchanged, original condition thus following the pontifical regulations. ${ }^{35}$

Two pedestals of the furnishing of the sanctuary have remained, probably bases of emperors' statues were placed on them, a fresco with the depiction of a Genius with a cornucopia and the related inscription dedicated to Genius and presumably also contains the affiliation (Genius cu(stodiarum?)) as well as the denomination of the building (tel(oneum?)) housing the sanctuary. The decoration of the sanctuary probably did not confine to a single, painted figure and the related inscription, i.e. the Genius and its inscription represents the fragment of a thematically coherent pictorial and inscriptive programme. Beside these, a statue of an eagle (aquila) came to light which due to its location was subject to religious respect and in this case it may have represented the state i.e. the imperial authority in the sanctuary of the public building. In front of the eastern wall, there were statues of emperors, behind them, on the wall, independently according to its pedestal, probably in a niche, stood the eagle. The fresco and its inscription slid off the northern wall.

Within the customs district (Publicum portorium Illyrici), the building is the example of the lesser known, local, municipal customs stations in which the identified sanctuary is a rare phenomenon even at imperial level. The existence and operation of the office was under direct imperial control and beside the officials it probably had armed guards, too, nevertheless it cannot be considered as a military object. The establishment and operation of the customs station may be related to the growing significance of Sopianae in the $3^{\text {rd }}$ century which is also supported by the archaeologically also detected, growing circulation of coins. ${ }^{36}$

\section{REFERENCES}

AEA 2011/2012

$\mathrm{AE}$

ANGUISSOLA 2002

BRAEMER 1999

\footnotetext{
= INGRID WEBER-HIDEN: Annona epigraphica Austriaca 2011-2012. Römisches Österreich 36. Wien 2013, 349-378.

= L'Année Épigraphique. Paris 1888-.

= A. ANGUISSOLA: Note alla legislazione su spoglio e reimpiego di materiali da costruzione ed arredi architettonici, I sec. a.C. - VI sec. d.C. In: Senso delle rovine e riuso dell'antico. Ed.: W. Cupperi. ASNP IV/14. Pisa 2002, 13-29.

$=$ F. BRAEMER: Le Corpus Signorum Imperii Romani. In: Proceedings of the XVth International Congress of Classical Archaeology. Classical archaeology towards the third millennium: reflexions and perspectives, Amsterdam, July 12-17. 1998. Eds: R. F. Docter, E. M. Moormann. Amsterdam 1999, 90-93.
}

sacrilegi ritus funestioribus locis exercere convivia vel quicquam sollemnitatis agitare. Episcopis quoque locorum haec ipsa prohibendi ecclesiasticae manus tribuimus facultatem; iudices autem viginti librarum auri poena constringimus et pari forma officia eorum, si haec eorum fuerint dissimulatione neglecta. Dat. XVII Kal. Dec. Romae Basso et Philippo conss. (408 [407] nov. 15). (text A. Koptev) Also for the mentality of the period on heritages, see e. g. SARADI-MENDELOVICI 1990, 47-61; ANGUISSOLA 2002, 13-29; CATTANI 2002, 31-44. ${ }^{35}$ See e. g. CIL VI 1884; CIL X 2 (p. 985) 8259; ILS 8381; FIRA I, 330-331, Nr. 63, 249, Nr. 76; MARQUARDT 1885, 310.

${ }^{36}$ See Tóтн 2006, 49-102. 
BRESSON 2016

Cattani 2002

CB

CIL

De LAET 1949

DoBÓ 1940

DOMASZEWSKI 1895a

DOMASZEWSZKI $1895 \mathrm{~b}$

DUPUIS 2000

FIRA

GudEA 1996

HimmELMANN-WindSCHÜTZ 1994

IK

ILLPRON

ILS

Kajanto 1965

KIENAST 2003

KIRCHHOF 2018

KovÁcs 2014

KRÜGER 1923

KUNCKEL 1974

LBIRNA

LECLERCQ 1926

LŐRINCZ 2002

MARQUARDT 1885

MOMMSEN-MEYER 1905

\section{PfLAUM}

PISO 2013

RE

SARADI-MENDELOVICI 1990

SCHOELL 2014

SESTON 1969

STEWART 2003

STOLl 2001

TÖPFER 2008

TÖPFER 2011
= A. BRESSON: A new procurator of the quadragesima Asiae at Apameia. In: Kelainai - Apameia Kibotos. Eine achämenidische, hellenistische und römische Metropole. Hrsg.: A. Ivantchik, L. Summerer, A. v. Kienlin. Bordeaux 2016, 301-329.

= P. CATTANI: La distruzione delle vestigia pagane nella legislazione imperiale tra IV e V secolo'. In: Senso delle rovine e riuso dell'antico. Ed.: W. Cupperi. ASNP IV/14. Pisa 2002, 31-44.

= E. SchallmayeR-K. Eibl-J. Ott-G. Preuss-E. Wittkopf: Der römische Weihebezirk von Osterburken. I.: Corpus der griechischen und lateinischen Beneficiarier-Inschriften des Römischen Reiches. Stuttgart 1990.

$=$ TH. Mommsen (cond.): Corpus Inscriptionum Latinarum. Berlin 1853-.

$=$ S. J. DE LAET: Portorium. Étude sur l'organisation douanière chez les Romains, surtout à l'époque du Bruges. Brugge 1949.

= Á. DoBÓ: Publicum Portorium Illyrici. DissPann II/6. Budapest 1940.

= A. von Domaszewski: 11) Der Legionsadler. In: RE II.1. Stuttgart 1895, 317-318.

= A. von DomaszewsZKI: Die Religion des römischen Heeres. WdZ 14 (1895) 1-142.

= X. DuPUIS: Les „IIII publica Africae“: un exemple de personnel administrativ subalterne en Afrique. Cahiers du Centre Gustave Glotz 11 (2000) 277-294.

$=\mathrm{S}$. RicCOBONO-G. BAVIERA-V. ARANGIO-RuIZ et al. (ed.): Fontes Iuris Romani Anteiustiniani I-III ${ }^{2}$ (I.: Leges; II.: Auctores; III.: Negotia). Firenze 1940-1943.

= N. GUDEA: Porolissum. Un complex daco-roman la marginea de nord a Imperiului Roman II. Vama romană. Monografie arheologică. Contribuții la cunoașterea sistemului vamal din provinciile dacice. Bibliotheca Musei Napocensis 12. Cluj-Napoca 1996.

= N. HimmELMANN-WildschüTZ: Römische Adler. In: Macht und Kultur im Rom der Kaiserzeit. Hrsg.: K. Rosen. Studium universale 16. Bonn 1994, 65-77.

$=$ Inschriften griechischer Städte aus Kleinasien, Bonn 1972-. IK 16= Die Inschriften von Ephesos. 6: Nr. 2001-2958. Bonn 1980.

= Inscriptionum Lapidarium Latinarum Provinciae Norici usque ad annum MCMLXXXIV repertarum indices. Berlin 1986.

$=$ H. DESSAU: Inscriptiones Latinae Selectae. I-III. Berlin 1892-1916.

= I. KaJAnto: The Latin Cognomina. Commentationes Humanarum Litterarum. 36/2. Helsinki-Helsingfors 1965 .

= D. KIENAST: Römische Kaisertabelle. Grundzüge einer römischen Kaiserchronologie. Darmstadt $2003^{3}$.

= A. KIRCHHOF: Painted depiction of Genius of Sopianae. ActaArchHung 69/1 (2018) 107-130.

= P. Kovács: A History of Pannonia during the Principate. Antiquitas I/65. Bonn 2014.

= P. KRÜGER: Codex Theodosianus. Berlin 1923

= H. KunCKEL: Der römische Genius. RM Ergänzungsheft 20. Heidelberg 1974.

= A. SAASTAMOINEN: The Phraseology and Structure of Latin Building Inscriptions in Roman North Africa. Helsiniki 2010.

$=$ H. LECLERCQ: Impots. In: DACL 7. Paris 1926, 416-463.

= B. LŐRINCZ: Onomasticon provinciarum Europae Latinarum (OPEL). IV.: Quadratia-Zures. Wien 2002.

= I. MARQUARDT: Römische Staatsverwaltung $\mathrm{III}^{2}$. Leipzig 1885.

$=$ Theodosiani libri XVI cum constitutionibus Sirmondianis. Ediderunt TH. MoMMSEN et P. M. MEYER. Berlin 1905.

$=$ H. G. Pflaum: Les carrières procuratoriennes équestres sous le Haut-Empire romain. Paris 19601961; 1982 (Suppl.).

= I. PISO: Fasti provinciae Daciae II. Antiquitas I/60. Bonn 2013.

= G. WissowA-W. Kroll-K. MitTelhaus (Hrsg.): Realencyclopädie der classischen Altertumswissenschaft. Stuttgart 1893-.

$=$ H. SARAdi-Mendelovici: Christian attitudes toward pagan monuments in late Antiquity and their legacy in later Byzantine centuries. DOP 44 (1990) 47-61.

= Iustiniani novellae, recognovit Rudolfus ScHOELL. Cambridge 2014.

= W. SESTON: Feldzeichen. In: RAC 7. Stuttgart 1969, 692-711.

= P. STEWART: Statues in Roman Society. Representation and Response. Oxford 2003.

= O. STOLL: Der Adler im »Käfig« zu einer Aquilifer-Grabstele aus Apamea in Syrien. In: O. Stoll: Römisches Heer und Gesellschaft. Gesammelte Beiträge 1991-1999. Stuttgart 2001, 13-46.

= K. TÖPFER: Der Adler der Legion. AW 5 (2008) 30-36.

$=$ K. TÖPFER: Signa Militaria - Die römischen Feldzeichen in der Republik und im Prinzipat. Monographien Razm 91. Mainz 2011. 
TóTH 2006

UbiEratLupa

VÁMOS 2008

Vatican 1986

VITTINGHOF 1953

WissowA 1912

ZPE
= E. То́тн: A pogány és keresztény Sopianae (A császárkultusz-központ Pannonia Inferiorban, valamint a pogány és keresztény temetkezések elkülönítésének a lehetőségéről: a II. sírkamra). [The Pagan and Christian Sopianae (The centre of the Imperial Cult in Pannonia Inferior, as well as about the separation's possibility of the Pagan and Christian burials: the II burial chamber)] SpecN 20 (2006) 49-102.

= O. HARL-F. HARL: Forschungsgesellschaft Wiener Stadtarchäologie. Datenbank zur Erfassung römischer Steindenkmäler: www.ubi-erat-lupa.org

= P. VÁMOs: Genius representation from the northern region of the Aquincum Miltary Town. In: Cultus Deorum. Studia religionum ad historiam. In memoriam István Tóth. II.: De rebus aetatis Graecorum et Romanorum. Ed.: Á. Szabó. P. Vargyas. Ókortudományi Dolgozatok [Papers of Antique Studies] 1 Pécs 2008, 251-258.

= Guide to the Vatican: Museums and City. Pontifical Monuments, Museums and Galleries. Tipografia Vaticana 1986.

= F. VitTINGHOFF: Portorium. In: RE XXII.1. Stuttgart 1953, 346-399.

$=\mathrm{G}$. Wissowa: Religion und Kultus der Römer ${ }^{2}$. München 1912.

$=$ Zeitschrift für Papyrologie und Epigraphik. Bonn 1967-. 
